\title{
Vertical transmission of SARS-CoV-2: a brief literature review
}

\author{
Mounir Moukit ${ }^{1 *}$, Assia El Ouardi², Abdellah Babahabib ${ }^{1,3}$, Mehdi El Hassani ${ }^{1,3}$, \\ Jaouad Kouach ${ }^{1,3}$
}

\begin{abstract}
${ }^{1}$ Department of Obstetrics and Gynecology, Military Training Hospital Mohammed V., Rabat, Morocco
${ }^{2}$ Department of COVID-19, University Hospital Center Hassan II, Fes, Morocco

${ }^{3}$ Department of Medicine and Pharmacy, University Mohammed V., Rabat, Morocco
\end{abstract}

Received: 22 May 2020

Accepted: 30 June 2020

\section{*Correspondence:}

Dr. Mounir Moukit,

E-mail: moukitmounir@yahoo.com

Copyright: () the author(s), publisher and licensee Medip Academy. This is an open-access article distributed under the terms of the Creative Commons Attribution Non-Commercial License, which permits unrestricted non-commercial use, distribution, and reproduction in any medium, provided the original work is properly cited.

\begin{abstract}
As COVID-19 virus is still spreading, more infections in pregnant women are likely to be seen. At this time, very little is known about vertical transmission of SARS-COV-2 from infected pregnant woman to her infant. Authors reviewed the risk of vertical transmission of COVID-19 by using data of published articles and official websites up to May 11, 2020. The searches revealed 16 articles (12 case reports/series and 4 retrospective studies) collectively comprising 194 infected pregnant women with COVID-19. 140 cases of neonates delivered from pregnant women with COVID-19 were collected. The SARS-COV-2 nucleic acid test, in day 2, was positive in 4 newborns. Based on limited data, there is no evidence for vertical transmission of COVID-19. Some studies suggestive of maternal-fetal transmission deserve careful evaluation before a definitive finding.
\end{abstract}

Keywords: Infected mother, Neonate, Pregnancy, SARS-CoV-2, Vertical transmission

\section{INTRODUCTION}

In December 2019, an outbreak of the 2019 coronavirus disease (COVID-19) associated pneumonia was identified firstly in Wuhan, China. Over the ensuing months, widespread transmission of severe acute respiratory syndrome coronavirus 2 (SARS-CoV-2), the virus that causes COVID-19, has been reported in all continents. As of May 11, 2020, there are approximately 2.435 .000 active cases in the world and 286.000 deaths. SARS-CoV-2 is the $7^{\text {th }}$ coronavirus identified to cause human infection, with the previous six species including 229E, NL63, OC43, HKU1, Middle East respiratory syndrome coronavirus (MERS-CoV) and SARS-CoV. ${ }^{1}$ Recently, Zhu et al, showed that SARS-CoV-2 has a $79.5 \%$ identity with SARS-CoV and $96 \%$ with a bat coronavirus. ${ }^{2}$ SARS-CoV-2 is highly infectious, with multiple possible routes of transmission. Respiratory droplets and close physical contact are thought to be the main transmission route. However, controversy exists regarding whether SARS-CoV-2 can be transmitted in utero from an infected mother. In this report, through a brief literature review, the authors try to discuss the possibility of vertical transmission of SARS-CoV-2.

\section{METHODS}

Authors reviewed the risk of vertical transmission of COVID-19 by using data of published articles and official websites up to May 11, 2020.

\section{RESULTS}

The searches revealed 16 articles (12 case reports/series and 4 retrospective studies) collectively comprising 194 infected pregnant women with COVID-19. The median gestational age at birth was 37 weeks and $13 \%$ of the infected mothers had a vaginal delivery. $10(5 \%)$ newborns were symptomatic and symptoms include: fever, shortness of breath, cyanosis, respiratory distress syndrome and feeding intolerance. Chest imagining abnormalities were found in 11 new-borns, but it was 
difficult to specify their origin (pathology related to pregnancy, preterm labor, labour dystocia or COVID-19). 140 cases of neonates delivered from pregnant women with COVID-19 were collected. The SARS-COV-2 nucleic acid test, in day 2, was positive in 4 new-borns. In Table 1, authors summarized the results of reported cases.

Table 1: Results of the reported cases.

\begin{tabular}{|c|c|c|c|c|c|c|c|}
\hline & $\mathbf{n}$ & $\begin{array}{l}\text { Median } \\
\text { gestational } \\
\text { age at birth } \\
\text { (weeks) }\end{array}$ & $\begin{array}{l}\text { Vaginal } \\
\text { delivery } \mathbf{N}^{0} \\
(\%)\end{array}$ & $\begin{array}{l}\text { Male } \\
\text { newborns } \\
\mathbf{N}^{0}(\%)\end{array}$ & $\begin{array}{l}\text { Symptomatic } \\
\text { newborns } \mathbf{N}^{0} \\
(\%)\end{array}$ & $\begin{array}{l}\text { Chest } \\
\text { imagining } \\
\text { abnormalities } \\
\mathbf{N}^{0}(\%)\end{array}$ & $\begin{array}{l}\text { Positive PCR of } \\
\text { nasopharyngeal } \\
\text { swab }\end{array}$ \\
\hline Li et $\mathrm{al}^{3}$ & 36 & 38 & $4(12 \%)$ & - & 0 & - & $\begin{array}{l}\text { No one in } 3 \\
\text { neonates }\end{array}$ \\
\hline Zeng et $\mathrm{al}^{4}$ & 33 & T3 & 0 & $3(10 \%)$ & $3(10 \%)$ & $3(10 \%)$ & $3(10 \%)$ in day 2 \\
\hline Liu et $\mathrm{al}^{5}$ & 19 & 38 & - & $13(68 \%)$ & 0 & - & 0 \\
\hline${\text { Breslin et } \mathrm{al}^{6}}^{6}$ & 18 & 37 & $10(55.5 \%)$ & - & 0 & - & 0 \\
\hline Zhang et $\mathrm{al}^{7}$ & 16 & \multicolumn{5}{|c|}{ No difference with women without COVID-19 (comparative study) } & $\begin{array}{l}\text { No one in } 10 \text { of } 16 \\
\text { neonates }\end{array}$ \\
\hline Yang et $\mathrm{al}^{8}$ & 13 & 38 & $4(30 \%)$ & $8(57 \%)$ & 0 & - & 0 \\
\hline Liu et $\mathrm{al}^{9}$ & 11 & 37 & $1(9 \%)$ & - & 0 & - & - \\
\hline Liu et $\mathrm{al}^{10}$ & 10 & 35 & 0 & - & 0 & - & 0 \\
\hline Zhu et $\mathrm{al}^{11}$ & 10 & 38 & - & $8(80 \%)$ & $6(60 \%)$ & $7(70 \%)$ & 0 \\
\hline Chen et al ${ }^{12}$ & 9 & 38 & 0 & - & 0 & - & $\begin{array}{l}\text { No one in } 6 \text { of } 9 \\
\text { neonates }\end{array}$ \\
\hline Yu et $\mathrm{al}^{13}$ & 7 & 39 & 0 & - & 1 & $1(14 \%)$ & $\begin{array}{l}1(14 \%) \text { after } 36 \\
\text { hours }\end{array}$ \\
\hline Chen et $\mathrm{al}^{14}$ & 4 & 38 & $1(25 \%)$ & $3(75 \%)$ & 0 & - & $\begin{array}{l}\text { No one in } 3 \\
\text { neonates }\end{array}$ \\
\hline Chen et $\mathrm{al}^{15}$ & 3 & T3 & 0 & - & 0 & 0 & 0 \\
\hline Tasnim $^{16}$ & 3 & T3 & - & - & 0 & 0 & 0 \\
\hline Dong et $\mathrm{al}^{17}$ & 1 & 38 & 0 & 0 & 0 & 0 & 0 \\
\hline Peng et al $^{18}$ & 1 & 35 & 0 & 0 & $1(100 \%)$ & 1 & 0 \\
\hline
\end{tabular}

PCR: polymerase chain reaction, T3: third trimester, COVID-19, 2019 coronavirus disease.

\section{DISCUSSION}

Vertical transmission is a common transmission route for some contagious disease, by which the pathogens passed from mother to infant across the placenta, through direct contact during delivery (when the baby descends in the birth canal) or in the breast milk. 229E, OC43, NL63 and HKU1 have proven to be characteristic of vertical transmission; on the other hand, maternal-fetal transmission of SARS-CoV and MERS is still not confirmed. ${ }^{19-21}$ In a Chinese cohort study, 3 of 33 newborns (9\%) presented with early onset SARS-CoV-2 infection ${ }^{4}$. In this study, authors explain that the sources of SARS-CoV-2 in the neonates' upper respiratory tracts or anuses were maternal because strict infection control and prevention procedures were implemented during the delivery. ${ }^{4}$ Given that viral testing was delayed, a postpartum neonatal infection acquired through an infected contact could not be eliminated. Although other studies have shown that there were no clinical findings or investigations suggestive of COVID-19 in neonates born to affected mothers, and all samples, including amniotic fluid, cord blood, neonatal throat swab, vaginal secretions, breast milk and urine samples from the newborn were negative for SARS-CoV-2, the intra uterine transmission cannot be ruled out. ${ }^{5-7}$ Dong et al, have reported a neonate born to a mother with COVID-19 with elevated antibody levels and abnormal cytokine test results two hours after birth. ${ }^{17}$ The elevated IgM antibody level suggests that the neonate was infected in utero. In fact, IgM antibodies are not transferred to the fetus via the placenta. Also, the laboratory results objectifying inflammation and liver injury indirectly support the possibility of vertical transmission. ${ }^{17}$ Nevertheless, newborn specimen reverse transcriptase - polymerase chain reaction (RT-PCR) test for SARS-CoV-2 was negative and consequently there is not virologic evidence for congenital infection to support the serologic suggestion of in utero transmission. The similar results were presented on another subsequent study, which sent the neonatal throat swab samples from 7 pregnant women with COVID-19 for nucleic acid test and one (14\%) sample is tested positive for SARS-CoV-2. ${ }^{13}$ Limitations of these reports include the single confirmed case and 
that no RT-PCR testing of amniotic fluid or placenta was performed. It is notable that the majority of reported cases acquired COVID-19 in the last trimester, and there is no data when the infection is acquired in early gestational age. Recently, Yu and his collaborators have reported SARS-CoV-2 negativity in amniotic fluid (performed between 16- and 18-weeks' gestation) from two pregnant women who were diagnosed with COVID19 in the early gestational age of pregnancy ( 8 weeks). ${ }^{22}$ In this report, the authors concluded that the possibility of vertical transmission in early and middle pregnancy could not be ruled out for several reasons: 1) RNA is much less stable in amniotic fluid compared with DNA, 2) the number of patients was insufficient to make a definite conclusion, 3 ) the virus might have been undetectable in amniotic fluid because of insufficient gestational age (the best time for amniocentesis is after 18-21 weeks' gestation). ${ }^{22}$ Possibility of viral load influencing vertical transmission risk must be taken into consideration. Previous studies have demonstrated a positive relationship between the viral load of some viruses and their ability to spread from mother to child, but it is still unclear whether SARS-CoV-2 has similar characteristics. ${ }^{23}$

\section{CONCLUSION}

The possibility of vertical transmission is of great concern to the obstetrician and neonatologist. To date, it should still be cautious to exclude vertical transmission, as the biological characteristics and pathogenesis of SARS-CoV-2 remains unclear. Further studies are still necessary to clarify this issue.

\section{Funding: No funding sources}

Conflict of interest: None declared

Ethical approval: Not required

\section{REFERENCES}

1. Chen Y, Liu Q, Guo D. Emerging coronaviruses: genome structure, replication, and pathogenesis. J Med Virol. 2020;92(4):418-23.

2. Zhu N, Zhang D, Wang W, Li X, Yang B, Song J, et al. A novel coronavirus from patients with pneumonia in China, 2019. N Engl J Med. 2020;382:727-33.

3. Li N, Han L, Peng M, Lv Y, Ouyang Y, Liu K, et al. Maternal and neonatal outcomes of pregnant women with COVID-19 pneumonia: a case-control study. Pre-print; 2020.

4. Zeng L, Xia S, Yuan W, Yan K, Xiao F, Shao J, et al. Neonatal early-onset infection with SARS-CoV-2 in 33 neonates born to mothers with COVID-19 in Wuhan, China. JAMA Pediatr. 2020:InPress.

5. Liu W, Wang J, Li W, Zhou Z, Liu S, Rong Z. Clinical characteristics of 19 neonates born to mothers with COVID-19. Front Med. 2020:Epub ahead of print.
6. Breslin N, Baptiste C, Gyamfi-Bannerman C, Miller $\mathrm{R}$, Martinez R, Bernstein K, et al. COVID-19 infection among asymptomatic and symptomatic pregnant women: two weeks of confirmed presentations to an affiliated pair of New York City hospitals. Am J Obstet Gynecol MFM. 2020:100118.

7. Zhang L, Jiang Y, Wei M, Cheng BH, Zhou XC, Li $\mathrm{J}$, et al. Analysis of the pregnancy outcomes in pregnant women with COVID-19 in Hubei province. Zhonghua Fu Chan Ke Za Zhi. 2020;55(0):E009.

8. Yang H, Sun G, Tang F, Peng M, Gao Y, Peng J, et al. Clinical features and outcomes of pregnant women suspected of coronavirus disease 2019. J Infect. 2020;81(1):e40-4.

9. Liu D, Li L, Wu X, Zheng D, Wang J, Yang L, et al. Pregnancy and perinatal outcomes of women with coronavirus disease (COVID-19) pneumonia: a preliminary analysis. Am J Roentgenol. 2020:1-6.

10. Liu Y, Chen H, Tang K, Guo Y. Clinical manifestations and outcome of SARS-CoV-2 infection during pregnancy. J Infect. 2020;S01634453(20):30109-2.

11. Zhu H, Wang L, Fang C, Peng S, Zhang L, Chang G, et al. Clinical analysis of 10 neonates born to mothers with 2019-nCoV pneumonia. Transl Pediatr. 2020;9(1):51-60.

12. Chen H, Guo J, Wang C, Luo F, Yu X, Zhang W, et al. Clinical characteristics and intrauterine vertical transmission potential of COVID-19 infection in nine pregnant women: a retrospective review of medical records. Lancet. 2020;395:809-15.

13. Yu N, Li W, Kang Q, Xiong Z, Wang S, Lin X, et al. Clinical features and obstetric and neonatal outcomes of pregnant patients with COVID-19 in Wuhan, China: a retrospective, single-centre, descriptive study. Lancet Infect Dis. 2020;20(5):559-64.

14. Chen Y, Peng H, Wang L, Zhao Y, Zeng L, Gao H, et al. Infants born to mothers with a new coronavirus (COVID-19). Front Pediatr. 2020;8:104.

15. Chen S, Huang B, Luo DJ, Li X, Yang F, Zhao Y, et al. Pregnant women with new coronavirus infection: a clinical characteristics and placental pathological analysis of three cases. Zhonghua Bing Li Xue Za Zhi. 2020;49:E005.

16. Tasnim Agency. Birth of a neonate from infected mother COVID-19 in Babol city, 2020. Available at: https://www.tasnimnews.com/fa/news/1398/12/14/22 16407/. Accessed on $4^{\text {th }}$ March 2020.

17. Dong L, Tian J, He S, Zhu C, Wang J, Liu C, et al. Possible vertical transmission of SARS-CoV-2 from an infected mother to her newborn. JAMA. 2020;323(18):1846-8.

18. Peng Z, Wang J, Mo Y, Duan W, Xiang G, Yi M, et al. Unlikely SARS-CoV-2 vertical transmission from mother to child: a case report. J Infect Public Health. 2020;:S1876-0341(20):30439-1.

19. Gagneur A, Dirson E, Audebert S, Vallet S, LegrandQuillien MC, Laurent $\mathrm{Y}$, et al. Materno-fetal transmission of human coronaviruses: a prospective 
pilot study. Eur J Clin Microbiol Infect Dis. 2008;27:863-6.

20. Ng PC, Leung CW, Chiu WK, Wong SF, Hon EK. SARS in newborns and children. Biol Neonate 2004;85:293-8.

21. Alserehi H, Wali G, Alshukairi A, Alraddadi B. Impact of Middle East Respiratory Syndrome coronavirus (MERS-CoV) on pregnancy and perinatal outcome. BMC Infect Dis. 2016;16(1):1-4.

22. Yu N, Li W, Kang Q, Zeng W, Feng L, Wu J. No SARS-CoV-2 detected in amniotic fluid in midpregnancy. Lancet Infect Dis. 2020; PMC7176395

23. Landes M, van Lettow M, Nkhoma E, Tippett Barr B, Truwah Z, Shouten E, et al. Low detectable postpartum viral load is associated with HIV transmission in Malawi's prevention of mother-tochild transmission programme. J Int AIDS Soc 2019;22:e25290.

Cite this article as: Moukit M, Ouardi AE, Babahabib A, Hassani ME, Kouach J. Vertical transmission of SARS-CoV-2: a brief literature review. Int J Reprod Contracept Obstet Gynecol 2020;9:3515-8. 